\title{
EVALUATION OF A LOCAL GOVERNMENT DEVELOPMENT PLANNING: THE CASE OF LATGALE
}

\author{
Sandra Ežmale \\ Rezekne Academy of Technologies, Latvia
}

\begin{abstract}
Spatial planning is a practical and useful instrument introduced by the European Community and national governments throughout the last decade with the aim to promote development of regions and reach territorial cohesion. In order to assess interconnections between quality of spatial planning documents of local governments of Latgale region and territorial development indicators the following tasks were performed: to describe the methodology for evaluation the quality of spatial planning documents, to describe the results of interconnections between quality of spatial planning documents in local governments of the region and development indicators.
\end{abstract}

Keywords: regional development, spatial planning, spatial plan, development programme.

\section{Introduction}

Spatial planning is a practical and useful instrument introduced by the European Community and national governments throughout the last decade with the aim to promote development of regions and reach territorial cohesion.

The spatial planning has been regarded in different ways; however, to principal approaches can be clearly distinguished:

1) as a system for management of spatial development and the physical use of land in a particular territory;

2) as a specific term to characterize a special spatial planning definition regarded as a co-ordination mechanism that has emerged in the result of discussions at the European level. (Dühr, Colomb \& Nadin, 2010)

The possibilities of spatial planning are related with its inter-disciplinary nature embracing the social and the economical fields, as well as cultural and environmental dimensions determining development trends of a region. The spatial planning has a great impact on territorial development.

The Latgale region considers itself in many ways as being a pioneer in regional development and planning in Latvia (Alden, Paalzow \& Ezmale). At the same time the region has the dubious distinction of being no only poorest Region in Latvia, but also one of the poorest in EU. Towns and cities is an important driving force of development of the entire state. At a concentrated level, they offer working places and lodging, which is supplemented by public 
and private services, as well as transport services and communications linking parts of towns and cities and ensure connection with other populated areas. Therefore, national and regional importance development centres according Latvia long-term development strategy 2035 was selected for present research, such as Daugavpils, Rēzekne, Balvi, Krāslava, Līvāni, Ludza, Preiḷi.

The objective of paper is to assess interconnections between quality of spatial planning documents of local governments of Latgale region and territorial development indicators. The following tasks were established:

to describe the methodology and results of evaluation the quality of spatial planning documents (development programmes, spatial plans and common spatial planning documents) of selected local governments of Latgale region;

to describe results on interconnections between quality of spatial planning in local governments and development indicators thereof, as well as the recent development tendencies of selected local governments of Latgale region.

Methods of the research for fulfilling the objectives of the article are following: logic analysis and synthesis methods, monographic and analytical methods of research of theoretical and empirical sources, descriptive statistical methods and correlation analysis method, indicators measurement and correlation analysis methods were applied.

\section{Key- Elements of good practice of Spatial Planning}

Many theoretical researches characterize the "good practice" of spatial planning documents by analysing the key-elements for elaboration of a highquality, effective and successful planning document. Therefore, it is important to analyse the most important criteria suggested in theoretical researches characterising compliance of spatial planning documents with the "good practice" of spatial planning. By summarizing conclusions, it can be concluded that the key-elements characterizing compliance of spatial planning documents with the "good practice" of spatial planning are as follows: (1) aims and objectives of a planning documents, planning horizon and status; (2) vertical and horizontal co-ordination; (3) integrated approach characterised by spatial, thematic and temporal strategy; (4) participation and awareness of the society; (5) strategic dimension or vision, aims and strategy; (6) an appropriate status and style of a document. (see Table 1).

There is a range of elements, observance of which is substantial for elaboration of a high-quality spatial planning document, and these elements are as follows: (1) the institutional, economic, environmental and social context; (2) 
a clear vision, aims and values, as well as a clear strategy for introduction of the latter; (3) the involvement a broad target groups during the entire process of document elaboration; (4) a well-considered and appropriate information and communication strategy aimed at target groups; (5) the relation with other field policy documents, as well as compatible with planning documents of a higher level; (6) a clear introduction mechanism to introduce resources, as well as to establish a simple though effective framework for monitoring activities. (Ežmale, 2012)

Table 1 Key-Elements of "Good Practice" of Spatial Planning and their Reflection in Planning Theory (Ežmale, 2012)

\begin{tabular}{|c|c|c|}
\hline $\begin{array}{c}\text { Key-elements of good } \\
\text { practice }\end{array}$ & $\begin{array}{l}\text { Examples of concepts in } \\
\text { theoretical researches }\end{array}$ & Authors \\
\hline $\begin{array}{l}\text { Horizontal and vertical co- } \\
\text { ordination has been ensured, } \\
\text { planning principles have } \\
\text { been established }\end{array}$ & $\begin{array}{l}\text { Horizontal co-ordination; } \\
\text { vertical co-ordination; } \\
\text { governance; governance } \\
\text { landscape; planning } \\
\text { principles }\end{array}$ & $\begin{array}{l}\text { Forinos (2004); Aldens } \\
\text { (2006); Adams \& Harris } \\
\text { (2006); Böhme (2002); } \\
\text { Böhme \& Waterhout (2008); } \\
\text { Healey (2009); Scheers } \\
\text { (2006); Forinos (2004) }\end{array}$ \\
\hline $\begin{array}{l}\text { Integrated approach (field, } \\
\text { spatial, a.o.) }\end{array}$ & $\begin{array}{l}\text { Thematic co-ordination; } \\
\text { spatial co-ordination; } \\
\text { balance between the } \\
\text { economic, social and } \\
\text { environmental fields; } \\
\text { planning in time; integrated } \\
\text { planning; temporal } \\
\text { dimension (continuities of } \\
\text { past, present and future) }\end{array}$ & $\begin{array}{l}\text { Nijkamp \& Pett (1989); } \\
\text { Myers \& Kitsuse (2000); } \\
\text { Adams (2006); Adams \& } \\
\text { Harris (2005); Alden (2006); } \\
\text { Healey, Khakee, Motte \& } \\
\text { Needham (1997); Alexander } \\
\text { (1998, 2000); Lichfield } \\
\text { (1998, 2001a); Olivera } \\
\text { (2010); Madanipour (2010) }\end{array}$ \\
\hline $\begin{array}{l}\text { Involvement of target } \\
\text { groups of the society and } \\
\text { information thereof has been } \\
\text { organized, political support } \\
\text { is present }\end{array}$ & $\begin{array}{l}\text { Collaborative planning); } \\
\text { participation potential; } \\
\text { leadership; interactive and } \\
\text { communicative approach; } \\
\text { planning and discussions; } \\
\text { community empowerment; } \\
\text { partnership approach; } \\
\text { involvement of the society; } \\
\text { actor relational approach }\end{array}$ & $\begin{array}{l}\text { Healey, Khakee, Motte \& } \\
\text { Needham (1997); Forester } \\
\text { (1989, 1999); Böhme (2002) } \\
\text { Adams \& Harris (2005); } \\
\text { Archibugi (2008); Aitken } \\
\text { (2010); Adams, Ezmale \& } \\
\text { Paalzow (2006); Abraham } \\
\text { (2000); Olsson (2009); } \\
\text { Fischler (2000); Boelen } \\
\text { (2010); Bäcklund \& } \\
\text { Mäntysalo (2010); Hudalah } \\
\text { (2010) }\end{array}$ \\
\hline $\begin{array}{l}\text { Vision and aims are clearly } \\
\text { defined, strategy for } \\
\text { reaching of them is } \\
\text { substantiated }\end{array}$ & $\begin{array}{l}\text { Strategic dimension; spatial } \\
\text { strategies, visioning; } \\
\text { structure of possibilities }\end{array}$ & $\begin{array}{l}\text { (Mintzberg, 1994); Myers \& } \\
\text { Kitsuse (2000); Albrecht } \\
\text { (2004); Scheers (2006); } \\
\text { Adams \& Harris (2005); } \\
\text { Healey, Khakee, Motte \& }\end{array}$ \\
\hline
\end{tabular}


Sandra Ežmale. Evaluation of a Local Government Development Planning: the Case of Latgale

\begin{tabular}{|l|l|l|}
\hline \multicolumn{1}{|c|}{$\begin{array}{c}\text { Key-elements of good } \\
\text { practice }\end{array}$} & $\begin{array}{l}\text { Examples of concepts in } \\
\text { theoretical researches }\end{array}$ & \multicolumn{2}{|c|}{ Authors } \\
\hline & & $\begin{array}{l}\text { Needham (1997); Healy } \\
(2009)\end{array}$ \\
\hline $\begin{array}{l}\text { Content of a document, } \\
\text { information, data and } \\
\text { analysis is appropriate to } \\
\text { reach the aim established in } \\
\text { a document and characterize } \\
\text { spatial structure }\end{array}$ & $\begin{array}{l}\text { Data amount; trends of } \\
\text { phanges in spatial } \\
\text { complexity continuity and }\end{array}$ & $\begin{array}{l}\text { Hillier \& Healey (2008); } \\
\text { Adams \& Harris (2005); } \\
\text { Alden (2006); Faludi, 2004) } \\
\text { Archibugi (2010) }\end{array}$ \\
$\begin{array}{l}\text { Style, terminology and } \\
\text { setting comply with the } \\
\text { identified document } \\
\text { audience }\end{array}$ & $\begin{array}{l}\text { Interpretive approach; actor } \\
\text { relational approach }\end{array}$ & $\begin{array}{l}\text { Innes (1995); Healey (1992) } \\
\text { Sager (1994); Adams \& } \\
\text { Harris (2005); Adams, Alden } \\
\text { \& Harris (2006) }\end{array}$ \\
\hline $\begin{array}{l}\text { Introduction and monitoring } \\
\text { procedures are clearly } \\
\text { defined }\end{array}$ & $\begin{array}{l}\text { Assessment; planning } \\
\text { introduction systems } \\
\text { Monitoring; indices }\end{array}$ & $\begin{array}{l}\text { Adams \& Harris (2005); } \\
\text { Tosics, Szemzo, Illes \& } \\
\text { Gertheis (2010); Adams, } \\
\text { Alden \& Harris (2006); } \\
\text { Olivera \& Pinho (2010); } \\
\text { Mehmood (2010) }\end{array}$ \\
\hline
\end{tabular}

\section{The methodology for evaluation of quality of spatial planning documents}

Based on the conclusions made as the result of analysis of theoretical aspects of spatial planning, methodology for assessment of quality of spatial planning documents was elaborated (Ežmale, 2011). The author applied multicriteria analysis method by establishing a matrix with two dimensions, one of which reflecting criteria for assessing spatial planning documents, the other their assessment in respect to different kinds of spatial planning documents. The criteria assessment algorithm (from 0 to 3 points) was established in a way to assess, by means of simple and clearly identifiable measures, compliance of a particular spatial planning documents with defined criteria.

The following eight criteria were established for assessment of quality of elaboration process of a spatial planning document: political mandate; purpose and status of the document; involvement of politicians; involvement of the society; information of the society; co-ordination of planning process; planning principles, and author of the document and management of elaboration. The maximum number of points that each local government could obtain for quality of planning and elaboration process of a development planning document is 24 (8 criteria from 0 to 3 points).

The following eight criteria were established for assessment of quality of content of a spatial planning document: analysis of the present situation; thematic dimension; spatial dimension; temporal dimension; vision, priorities and aims; introduction of strategy; clarity of the text, and style and form. The 
maximum number of points that each local government could obtain for quality of content of a spatial planning document is 24 (8 criteria from 0 to 3 points).

The following three criteria were established for assessment of quality of procedures for introduction and monitoring of a spatial planning document: procedure of introduction; procedure of monitoring; indices and indicators. The maximum number of points that each local government could obtain for quality of procedures for introduction and monitoring of a spatial planning document is 9 (3 criteria from 0 to 3 points).

Pursuant to the elaborated methodology and the matrix, the author performed an empirical research of local governments cities and towns of Latgale region regarding compliance of the spatial planning document (development programme and territorial plan) with defined criteria and algorithm of assessment.

The assessment of local governments ( 2 cities and 5 towns) of Latgale region is summarized in the Table 2 .

Table 2 Results of assessment of spatial planning documents of local governments of Latgale region, 2009 (Ežmale, 2011)

\begin{tabular}{|c|c|c|c|c|c|c|c|c|}
\hline \multirow{2}{*}{$\begin{array}{c}\text { Local } \\
\text { Government }\end{array}$} & \multicolumn{2}{|c|}{$\mathbf{1}^{\text {st competence }}$} & \multicolumn{2}{|c|}{$\mathbf{2}^{\text {nd }}$ competence } & \multicolumn{2}{|c|}{$\mathbf{3}^{\text {rd competence }}$} & \multicolumn{2}{|c|}{ Total } \\
\cline { 2 - 9 } & $\begin{array}{c}\text { DP } \\
\text { process }\end{array}$ & $\begin{array}{c}\text { TP } \\
\text { process }\end{array}$ & $\begin{array}{c}\text { DP } \\
\text { content }\end{array}$ & $\begin{array}{c}\text { TP } \\
\text { content }\end{array}$ & $\begin{array}{c}\text { DP } \\
\text { intro- } \\
\text { duction }\end{array}$ & $\begin{array}{c}\text { TP } \\
\text { intro- } \\
\text { duction }\end{array}$ & $\begin{array}{c}\text { DP } \\
\text { total }\end{array}$ & $\begin{array}{c}\text { TP } \\
\text { total }\end{array}$ \\
\hline \multicolumn{7}{|c|}{ Local governments of towns and cities } \\
\hline Livāni & 14 & 15 & 20 & 18 & 8 & 0 & 42 & 33 \\
\hline Rēzekne & 16 & 18 & 22 & 18 & 7 & 0 & 45 & 36 \\
\hline Ludza & 12 & 12 & 22 & 16 & 9 & 0 & 43 & 28 \\
\hline Daugavpils & 19 & 16 & 20 & 8 & 8 & 3 & 47 & 27 \\
\hline Balvi & 15 & 22 & 18 & 16 & 0 & 0 & 33 & 38 \\
\hline Preil̦i & 8 & 16 & 15 & 10 & 1 & 0 & 24 & 26 \\
\hline Krāslava & 15 & 22 & 19 & 15 & 6 & 0 & 40 & 37 \\
\hline
\end{tabular}

DP - development programme, TP - spatial plan, process - process of elaboration and planning of a planning document, content - content of a planning document, introduction - introduction and monitoring of a planning document.

As it can be seen in Table 2, higher results in evaluation of quality of development programmes were obtained by Daugavpils, Rēzekne, Ludza whilst Preili and Balvi have the lowest results. In the assessment of quality of spatial plans, the highest results are obtained by Balvi, Krāslava, whilst the lowest ones - Preili, and Daugavpils. The procedure of introduction and monitoring of spatial planning documents was the weakest of the three evaluated stages. 
Assessment of quality of spatial planning documents of local governments of Latgale region shows (calculated by summarizing the score obtained at each of the assessment stages) that the results for spatial plans are higher than those for development programmes. This can be explained, that for elaboration of spatial plans were clear rules for a content, elaboration, assessment and public involvement process in Latvia, whilst for development programmes it has been introduced in last years.

According the methodology for calculation the integral quality indicators of spatial planning documents (development programmes, spatial plans and common spatial planning documents) of Latgale region (Ezmale, 2012), the integral quality indicators for development programmes and territorial plans are obtained by summarising the standardized values of results obtained in the evaluation of the three components regarding quality of spatial planning documents based on established weight $\left(1^{\text {st }}\right.$ component $-0.3,2^{\text {nd }}$ component 0.3 , and $3^{\text {rd }}$ component -0.4$)$. The integral quality indicator of development programmes $\left(y_{D P}\right)$ and the integral quality indicator for spatial plans $\left(y_{T P}\right)$ are being calculated, which can be illustrated by the following formula:

$$
y=w_{1} \sum_{i=1}^{8} \tilde{S}_{i}+w_{2} \sum_{i=1}^{8} \tilde{P}_{i}+w_{3} \sum_{i=1}^{3} \tilde{I}_{i}
$$

where $\tilde{S}_{i}, \tilde{P}_{i}, \tilde{I}_{i}$ are the weighted criteria in the division by components, whilst the weight $w_{j}(\mathrm{j}=1,2, \ldots, \mathrm{p})$, which is calculated from the index (indicator) $\mathrm{y}-$ conditions for increasing awareness.

The formula for calculating the integral indicator that characterizes the common quality of spatial planning documents according the methodology are following:

$$
\mathrm{y}_{\mathrm{TPD}}=\frac{1}{\mathrm{n}}\left(\mathrm{y}_{\mathrm{DP}}+\mathrm{y}_{\mathrm{TP}}\right)
$$

The obtained results are reflected in Table 3.

Pursuant to the integral quality indicator of spatial planning documents, the highest scores were obtained by Daugavpils, Rēzekne, Līvāni, Ludza, and Krāslava local governments.

According the results of evaluation, the interrelation between the integral quality indicators of spatial planning documents of Latgale local governments and indicators characterising territorial development Ežmale (2012) settled, that in the frameworks of the selected cities and towns, there exist correlations between indicators of quality of spatial planning documents and several 
indicators of territorial development. It was concluded, that local governments of towns and cities having a higher integral quality indicators regarding spatial planning have greater personal incomes and greater number of inhabitants. There were calculated, that negative correlation exists between the integral quality indicators of territorial plans and the unemployment rate- as the integral quality indicators regarding territorial plans increase, the unemployment rate decreases.

Table 3 Integral quality indicators of spatial planning documents of local governments of Latgale region, 2009 (Ežmale, 2011)

\begin{tabular}{|l|c|c|c|c|}
\hline \multicolumn{1}{|c|}{ Local } \\
governments & $\begin{array}{c}\text { Integral quality } \\
\text { indicator of } \\
\text { development } \\
\text { programmes } \\
\text { (y }\end{array}$ & $\begin{array}{c}\text { Integral } \\
\text { quality } \\
\text { indicator of } \\
\text { spatial plans } \\
\left(\mathrm{y}_{\mathrm{TP}}\right)\end{array}$ & $\begin{array}{c}\text { Integral quality } \\
\text { indicator of of } \\
\text { spatial planning } \\
\text { documents } \\
\left(\mathrm{y}_{\mathrm{TPD}}\right)\end{array}$ & $\begin{array}{c}\text { Rank of the } \\
\text { local } \\
\text { government }\end{array}$ \\
\hline Daugavpils & 1.65 & 0.234 & 0.942 & 1 \\
\hline Rēzekne & 1.454 & 0.181 & 0.8175 & 2 \\
\hline Preili & 0.036 & -0.665 & -0.3145 & 7 \\
\hline Ludza & 1.546 & -0.41 & 0.568 & 5 \\
\hline Līiāni & 1.425 & -0.026 & 0.6995 & 3 \\
\hline Balvi & 0.314 & 0.277 & 0.2955 & 6 \\
\hline Krāslava & 1.162 & 0.187 & 0.6745 & 4 \\
\hline
\end{tabular}

Author concluded, that in the selected group of local governments, certain interrelations exist between integral quality indicators of spatial planning documents and territorial development indicators, as well as elaboration of spatial planning documents and a positive dynamics of territorial development index. Taking into account that spatial planning documents have middle- term and long- term time horizon, it could be necessary to analyse tendencies of main territorial development indicators in selected local governments. According the results of previous mentioned evaluation, the following indicators are selected territorial development index, number of population, unemployment rate and persons with poor family status from total number of inhabitants.

\section{Territorial development indicators of Latgale cities and towns}

Economic growth became slower due to various internal and external factors, among which the most important are the global crisis, escalation of the geopolitical situation, introduction of trade sanctions and the Russian economic recession, low economic growth in the euro area, as well as the sharp fall in oil 
prices in late 2014. The economy of Latvia is slowly accelerating, but the growth rate is not as strong as expected, and the territorial development index (TDI) of Latgale region cities and towns slowed down in last five years (see Table 4). The development of local governments of Latgale region have been particularly affected by economic downtown in 2009.

TDI is an indicator which is calculated with determined weight coefficients by summing up standardised values of the most important basic indicators of statistics which characterise the development. A territory development index (TDI) has been used for the assessment of development of different territorial units in Latvia.

Table 4 Territorial development index of local governments of Latgale region, 20092014 (source: RDIM)

\begin{tabular}{|l|c|r|r|r|r|}
\hline $\begin{array}{c}\text { Local } \\
\text { governments }\end{array}$ & $\mathbf{2 0 0 9}$ & $\mathbf{2 0 1 0}$ & $\mathbf{2 0 1 1}$ & \multicolumn{1}{c|}{$\mathbf{2 0 1 3}$} & \multicolumn{1}{c|}{$\mathbf{2 0 1 4}$} \\
\hline Daugavpils & -0.504 & -0.693 & -0.680 & -1.309 & -1.392 \\
\hline Rēzekne & -1.585 & -1.796 & -1.931 & -2.028 & -2.257 \\
\hline Balvi* & -0.617 & -0.647 & -0.591 & -0.821 & -0.864 \\
\hline Krāslava* & -0.903 & -1.009 & -0.1000 & -1.035 & -1.094 \\
\hline Līvani* & -0.765 & -0.598 & -0.622 & -0.747 & -0.625 \\
\hline Ludza* & -0.978 & -1.020 & -0.992 & -0.951 & -1.007 \\
\hline Preilï* & -0.173 & -0.255 & -0.223 & -0.810 & -0.347 \\
\hline
\end{tabular}

*together with rural parishes according the territorial division of territorial administrative reform of Latvia

The most dramatic decrease of territorial development index in last five years is recognised in two cities - Daugavpils (-0.888) and Rēzekne (-0.672).

One of the important indicators for characterising the territorial development is number of population and its changes. According the Regional development indicators module data (RDIM) of the Ministry of Environmental Protection and Regional Development of Latvia (see Table 5) the lowest decrease of number of population is in Daugavpils - by 5.46 percent. However, there is observed decline of population in all selected local governments and the population change (from 2010 to 2014) differences between the cities and towns is undistinguished.

In the ten-year period in the Latvian regions there can be observed tendencies of movement of population that simultaneously are different for each region and at the same time stable. (VRAA, 2010). In the period 2010-2014 the population number decreased most rapidly in Ludza - by 8.57 percent; in Kraslava - by 8,09 percent. The most rapid decrease of population is observed in the towns, which are located in close proximity with external border of European Union. 
Proceedings of the International Scientific Conference. Volume IV, May $27^{\text {th }}-28^{\text {th }}$, 2016. 267-277

Table 5 Number of population at beginning the year of local governments of Latgale region, 2010 - 2014 (source: RDIM)

\begin{tabular}{|l|r|r|r|r|r|r|}
\hline \multicolumn{1}{|c|}{ Local governments } & \multicolumn{1}{c|}{$\mathbf{2 0 1 0}$} & $\mathbf{2 0 1 1}$ & $\mathbf{2 0 1 2}$ & $\mathbf{2 0 1 3}$ & $\mathbf{2 0 1 4}$ & $\begin{array}{c}\text { Changes, } \\
\text { \% }\end{array}$ \\
\hline Balvi & 15,674 & 13,949 & 15,228 & 14,972 & 14,606 & -6.814 \\
\hline Daugavpils & 103,754 & 102,496 & 101,057 & 100,006 & 98,089 & -5.460 \\
\hline Krāslava & 19,983 & 19,679 & 19,277 & 18,936 & 18,366 & -8.092 \\
\hline Līvāni & 14,134 & 13,906 & 13,680 & 13,538 & 13,251 & -6.247 \\
\hline Ludza & 15,844 & 15,456 & 15,178 & 14,900 & 14,486 & -8.571 \\
\hline Preiḷi & 11,826 & 11,662 & 11,450 & 11,239 & 10,930 & -7.577 \\
\hline Rēzekne & 35,148 & 34,596 & 33,936 & 33,438 & 32,630 & -7.164 \\
\hline
\end{tabular}

One of the basic indicators describing the availability of human resources as well as social situation in the territories is unemployment level. Latgale region maintained the highest unemployment level during the long period, which was $17.8 \%$ at the end 2015. The lowest level of unemployment is in Daugavpils - 6.88 percent in 2014, the highest - in Ludza with 17.54 in 2014 (see Table 6).

Table 6 Unemployment rate of local governments of Latgale region, 2010 - 2014 (\%) (source: RDIM)

\begin{tabular}{|l|r|r|r|r|r|r|}
\hline $\begin{array}{l}\text { Local } \\
\text { governments }\end{array}$ & \multicolumn{1}{l|l}{ 2010 } & \multicolumn{1}{l|}{ 2011 } & \multicolumn{1}{l|}{$\mathbf{2 0 1 2}$} & \multicolumn{1}{l|}{$\mathbf{2 0 1 3}$} & \multicolumn{1}{l|}{$\mathbf{l 1 4}$} & \multicolumn{1}{l|}{ Changes } \\
\hline Balvi & 18.67 & 18.21 & 14.97 & 15.53 & 14.50 & -4.17 \\
\hline Daugavpils & 9.59 & 8.02 & 7.12 & 7.64 & 6.88 & -2.71 \\
\hline Krāslava & 19.63 & 17.52 & 15.54 & 16.19 & 11.94 & -7.69 \\
\hline Līvāni & 17.93 & 16.24 & 16.11 & 16.64 & 15.02 & -2.91 \\
\hline Ludza & 22.82 & 20.14 & 17.51 & 17.96 & 17.54 & -5.28 \\
\hline Preilui & 16.73 & 14.02 & 11.90 & 12.49 & 12.41 & -4.32 \\
\hline Rēzekne & 16.92 & 14.73 & 13.19 & 13.67 & 11.45 & -5.47 \\
\hline
\end{tabular}

The most rapid decrease of the unemployment level is observed in Krāslava, Ludza and Rēzekne.

The persons with poor family status is important indicator for analysing ability of local government to improve the economic situation. The highest share of persons with poor family status receiving the subsidies from municipal budget in from total number of inhabitants is in Ludza- 12.90 and Krāslava- 9,37 in 2014 (see Table 7).

The most rapid decrease of persons with poor family status from total number of inhabitants is in Rēzekne (-15.93), Balvi (-15.20) and Līvāni (-13.90). 
Table 7 Persons with poor family status local governments of Latgale region 2010 - 2014 (\%) (source: RDIM)

\begin{tabular}{|l|r|r|r|r|r|r|}
\hline $\begin{array}{l}\text { Local } \\
\text { governments }\end{array}$ & \multicolumn{1}{l|l}{ 2010 } & \multicolumn{1}{l|}{ 20112 } & \multicolumn{1}{l|}{ 2013 } & \multicolumn{1}{l|}{ 2014 } & Changes \\
\hline Balvi & 23.45 & 19.38 & 13.94 & 10.58 & 8.25 & -15.20 \\
\hline Daugavpils & 5.47 & 6.60 & 6.02 & 4.99 & 4.58 & -0.89 \\
\hline Krāslava & 18.85 & 12.40 & 13.07 & 11.54 & 9.37 & -9.48 \\
\hline Līvāni & 20.82 & 11.54 & 12.56 & 9.41 & 7.73 & -13.09 \\
\hline Ludza & 15.03 & 14.29 & 14.65 & 13.54 & 12.90 & -2.13 \\
\hline Preilii & 8.43 & 8.97 & 7.84 & 7.51 & 5.80 & -2.63 \\
\hline Rēzekne & 24.58 & 12.93 & 12.31 & 9.66 & 8.65 & -15.93 \\
\hline
\end{tabular}

According the previous mentioned results of evaluation of quality of development programmes and spatial plans, the highest results were obtained by Daugavpils, Rēzekne, Balvi. At the same time Rēzekne and Daugavpils have lowest territorial development index from selected local governments, Ludza and Krāslava - the most rapid decrease of population in last 5 years, as well as Krāslava, Ludza and Rēzekne - the best results in reducing of unemployment level.

In the frame of the research (Ežmale, 2011) were concluded that the analysis regional competitiveness factors and criteria is insufficient in spatial planning documents of Latgale region; therefore, it fails to ensure a wholesome use of potential of the region to favour its development. There was suggested that through elaboration of planning documents, Latgale region local governments should pay greater attention to the aspects of the business attractiveness. It would convince local entrepreneurs, potential investors that the local authority takes all necessary measures to improve the business climate and increase competitiveness in the city or town. By providing measures to increase the competitiveness factor within the city in spatial planning documents, it would create favourable conditions for business attractiveness improvement in the future.

\section{Conclusion}

Spatial planning documents of the region define development trends for different territories and places in the future in the context of their strategic roles; likewise, they define frameworks for establishment and improvement of future development. The results of the research prove that it is necessary to additionally define principles and development trends in respect to different fields of activities related with spatial issues, which would ensure integrated 
approach; moreover, spatial planning should be aimed at target groups (business, inhabitants, visitors) taking into account needs and desires of each of them.

Substantial correlations between integral indicator of quality of spatial planning documents and indicator of territorial development can be observed in local governments of cities and towns. The local governments of Latgale region having a higher quality of spatial planning documents have better conditions for territorial development.

\section{References}

Adams, N., Ezmale, S., \& Paalzow, A. (2006). Towards Balanced Development in Latvia: The Experience of the Latgale Region. Regional Development and Spatial Planning in an Enlarged European Union./ Ed. Adams, N., Alden, J., Harris, N. Ashgate, 199 - 220.

Dühr, S., Colomb, C., \& Nadin, V. (2010). European Spatial Planning and Territorial Cooperation. London: Routledge.

Ežmale, S. (2011). Latvijas regionu attīstība un telpiskā plānošana. Eiropas Savienības politiku kontekstā. Promocijas darbs. Daugavpils Universitāte, Sociālo zinātņu fakultāte, Ekonomikas katedra.

Ežmale, S. (2012). Latvijas reǵionu attīstība un telpiskāa plānošana Eiropas Savienības politiku kontekstā. Promocijas darba kopsavilkums. RA izdevniecība.

Ezmale, S., \& Litavniece, L. (2011). Spatial Planning as a Tool for Improving Attractiveness of the Places: Case of Latgale. Region. European Integration Studies No 5. Kaunas University of Technology, 2011. 20-25

VRAA. Territorial Development Index. Downloaded from http://www.vraa.gov.lv/lv/ petnieciba/attistibas_indekss/

VRAA (2010). Reǵionu attīstība Latvijā 2010. Downloaded from http://www.vraa.gov.lv/lv/ parskats/2010/ 